\title{
PROCESS OF FIXATION, IMOBILIZATION AND MINERALIZATION OF AMMONIUM IN SOIL USING N-15*
}

\author{
A. M. SaRavia ** \\ A. M. LOUIS Neptune ***
}

\section{RESUMO}

As formas de nitrogênio do solo e a maneira em que as mesmas participam dos processos de fixação, imobilização e mineralização do amônio no solo foram avaliadas após diferentes períodos de incubação, utilizando dois solos, um Lithic Haplustoll e um Typic Eutrorthox.

As formas analisadas através do conteúdo de nitrogênio e da relação isotópica ${ }^{15} \mathrm{~N} /{ }^{14} \mathrm{~N}$ foram: amônio trocável, amônio fixado, aminoácidos, hexosaminas, hidroxiaminoácidos, amônio do hidrolisado e nitrogênio total do hidrolisado.

Verificou-se que: 1) o método que emprega a extração com $\mathrm{KC1} 2 \mathrm{~N}$ para determinar a capacidade de fixação do amônio adicionado, está sujeito a erros provocados pela interferência de outras funções do solo, na fixação de amônio; 2) o aumento no conteúdo de amônio trocável está relacionado com a diminuição dos aminoácidos e do amônio do hidrolisado dos solos e 3) os processos de retenção e liberação do nitrogênio do solo continuam em condições de atividade microbiana nula, sendo as formas mais afetadas aminoácidos e amônio do hidrolisado.

\section{INTRODUCTION}

The best approach to the problem of analysis of soil nitrogen for guide on the use of fertilizers consist of the following steps:

a. determination of the most import forms of soil nitrogen.

b. determination of the participation of these forms in the process of soil nitrogen fixation, immobilization and mineralization.

* Research supported in part by the Comissão Nacional de Energia Nuclear. Received for publication in 30.12 .1976 .

* Estación Experimental 33 - La Estanzuela - Ministerio de Agricultura y Cria - Uruguay.

** Departamento de Solos e Geologia e Divisão de Ciências do Solo do Centro de Energia Nuclear na Agricultura - ESALQ, USP. 
c. determination of the influence of the plant on the evaluation of these processes.

d. calibration, in a greenhouse or in the field, of the methods for analysis of those forms which account for the supply of nitrogen to the plant, to be finally included in the routine analyses for recommendation of fertilizers.

Althrough there are methods for measurement of soil capacity to supply nitrogen through incubation, either aerobic or anaerobic, the time taken by soil sample analyses make it unwise to be adapted in laboratory routine analyses.

The present study is directed towards determining, for two soil units of Piracicaba County, State of São Paulo, the following:

1. the different forms, both organic and inorganic, of soil nitrogen.

2 . the ammonium fixation in the soil.

3 . the forms in which the soil ammonium and the added ammonium are fixed or immobilized.

4. the measurement, during a determined period of time, of the immobilized $\mathrm{N}$ mineralization.

\section{MATERIAL AND METHODS}

\subsection{Soils}

Two different soil types were selected concerning content and clay types, having in view of a better characterization of soil nitrogen fixation, immobilization and mineralization phenomena. They were classified as Lithic Haplustolls and Typic Euthorthox respectively (RANZANI et al., 1966; DEMATTÊ and ESCOBAR, 1969) .

The correspondent chemical and mineralogical analyses are shown in Table 1.

\subsection{Treatments and nitrogen fractionation scheme}

Two levels of nitrogen were used: $0 \mathrm{ppm}$ and $42 \mathrm{ppm}$. As a nitrogen source, a solution of $0,003 \mathrm{~N}$ ammonium sulphate with $29,47 \%$ atoms $\mathrm{N}^{15}$ in excess was used. Duplicates of $15 \mathrm{~g}$ of each of the soils were 
TABLE 1 - CHEMICAL AND MINERAlogicAl ANALySis OF THE SOILS

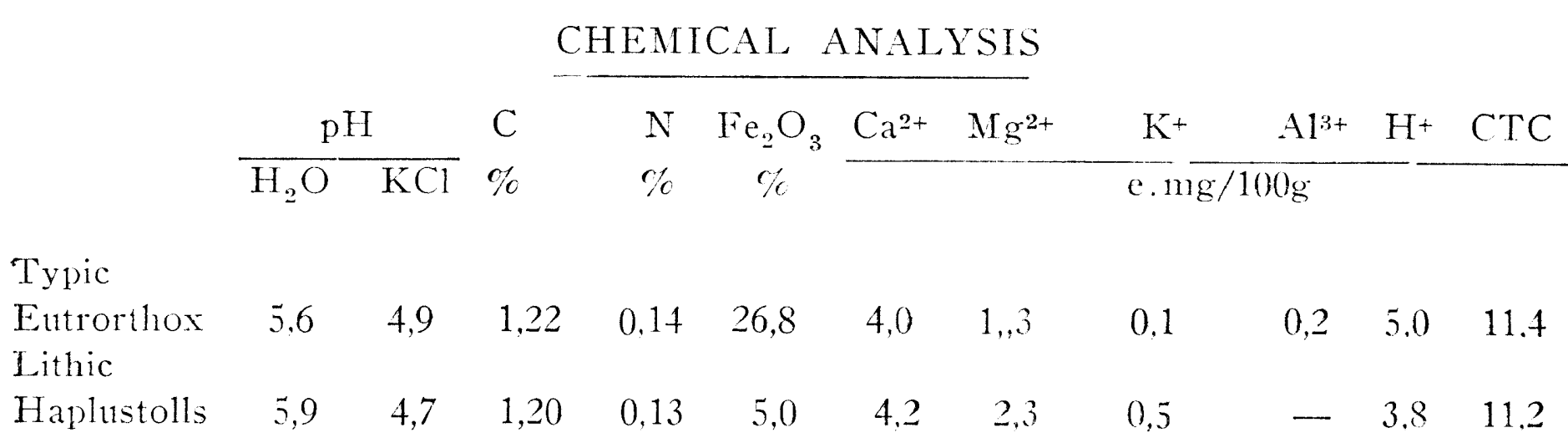

Typic

\begin{tabular}{|c|c|c|c|c|c|c|c|c|c|c|}
\hline & & & MIN & RAI & OGIC & YSIS & & & & \\
\hline & & oarse & clay & $2-0.2^{*}$ & & & Fine & lay & $0,2 \mu)$ & \\
\hline & C & $\mathrm{M}$ & $\mathrm{V}$ & $\mathrm{A}$ & $\mathrm{T}$ & C & $M$ & $\mathrm{~V}$ & $A$ & $T$ \\
\hline Typic & & & & & & & & & & \\
\hline Eutrorthox & 79,0 & 0,7 & 0,5 & 12,5 & 103,7 & 79,0 & 1,4 & 0,7 & 13,6 & 103,5 \\
\hline Lithic & & & & & & & & & & \\
\hline Haphustolls & 23,0 & 48,4 & 10,0 & 9,2 & 90,6 & 51,0 & 18,0 & 8,0 & 13,9 & 90,6 \\
\hline
\end{tabular}

placed in $250 \mathrm{ml}$ Erlenmeyer flasks, to which $15 \mathrm{ml}$ of the solution of $0,003 \mathrm{~N}$ ammonium sulphate with $29,47 \% \mathrm{~N}^{15}$ atoms excess was aggregated for the $42 \mathrm{ppm} \mathrm{N}$ treatment and $15 \mathrm{ml}$ water for the $0 \mathrm{~N}$ treatment. This soil-solution ratio developed an anerobic environment, what made the ammonium the terminal product of the mineralization processes during the incubation periods. This method was preferred to the aerobic one in view of the inherent difficulties of the latter (BREMNER, 1967; OLSON, 1960). The flasks were stoppered and incubated during 0,2 , 5,15 and 30 days in a oven at $30^{\circ} \mathrm{C}$ in order to determine the influence of time on the phenomena to be studied.

To halt the influence of soil microbiological processes on the nitrogen fixation and immobilization and study the possibility of discriminating the biological from the non biological retention, equal amounts of soil and solution were placed in $250 \mathrm{ml}$ Erlenmeyer flasks, stoppered with cotton and autoclaved at $120^{\circ} \mathrm{C}$ and a pressure of 2 atmospheres, during 20 minutes. 
After this time, the soil samples were incubated for the mentioned periods.

The nitrogen fractionation followed the scheme below:

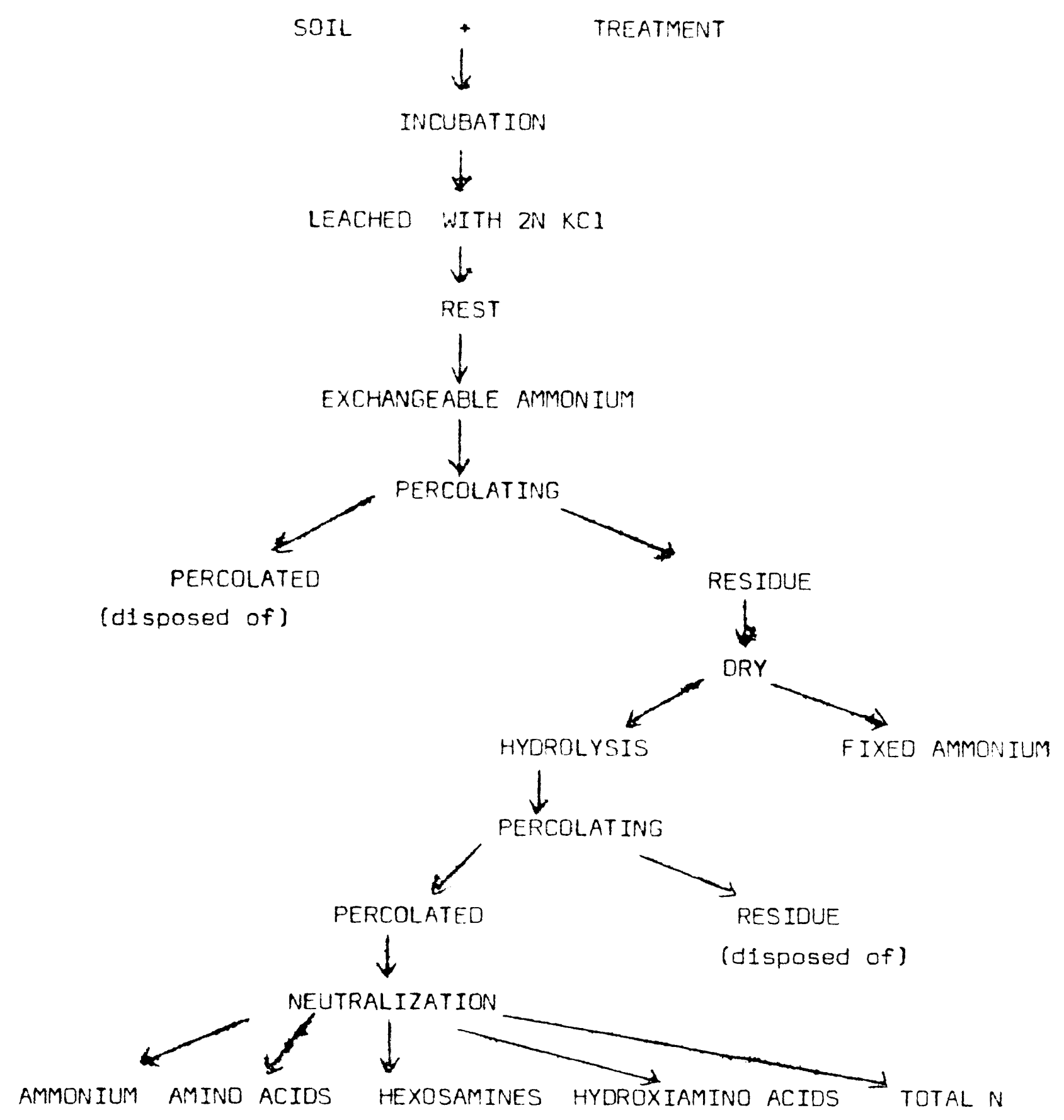




\subsection{Methods used for determination of the different forms of} nitrogen.

To determine the exchangeable ammonium the method of BREMNER and KEENEY, 1966 was followed. To analyze the ammonium fixation capacity of the two types of soils, the methods recommended by SILVA \& BREMNER, 1966, by ALLISON et al., 1953a, and by NÕMMIK, 1965 were used.

The fixed ammonium was determined according to SILVA \& BREMNER, 1966. To perform the hydrolysis and to determine the other forms of nitrogen in the hydrolyzate, BREMNER's method, 1959, was used. The difference between the total nitrogen in the hydrolyzate and the nitrogen of the amino acids + hexoseamines + hydroxyamino acids + ammonium was considered the non identifiable fraction of the hydrolyzate (KEENEY \& BREMNER, 1966). Total nitrogen was determined as per CATANI et al., 1955.

\subsection{Analysis of the $\left({ }^{15} \mathrm{~N} /{ }^{14} \mathrm{~N}\right)$ isotopic ratio}

In all the aforementioned chemical analysis methods, the different nitrogenous forms are transformed into ammonia, which is received in a boric acid solution, titrated with $\mathrm{H}_{2} \mathrm{SO}_{3}, 0,005 \mathrm{~N}$ and kept in acid medium for subsequent analysis on the mass spectrometer (BREMNER, 1965c). The distilling apparatuses used were those described by BREMNER and EDWARDS, 1965.

According to the nitrogen enrichment of the samples, aliquot parts were pippeted into Rittenberg tubes and treated by the techniques described by RITTENBERG, 1946. The analysis of the ${ }^{15} \mathrm{~N} /{ }^{14} \mathrm{~N}$ ratio in the samples was carried out on a mass spectrometer built by Atlas Mat (BREMEN), model CH-4 and calculated as per RITTENBERG, 1946, by the equation:

$$
\% \text { of }{ }^{15} \mathrm{~N} \text { atoms }=\frac{100}{2 \mathrm{R}+1}
$$

were $R$ is the quocient for peaks 28 and 29 ratio, from which the contributions of the background of the apparatus and of peak 32 were subtracted.

\section{RESULTS AND DISCUSSION}

\subsection{Forms of soil nitrogen}

Table 2 shows the data corresponding to the forms of nitrogen analysed. 


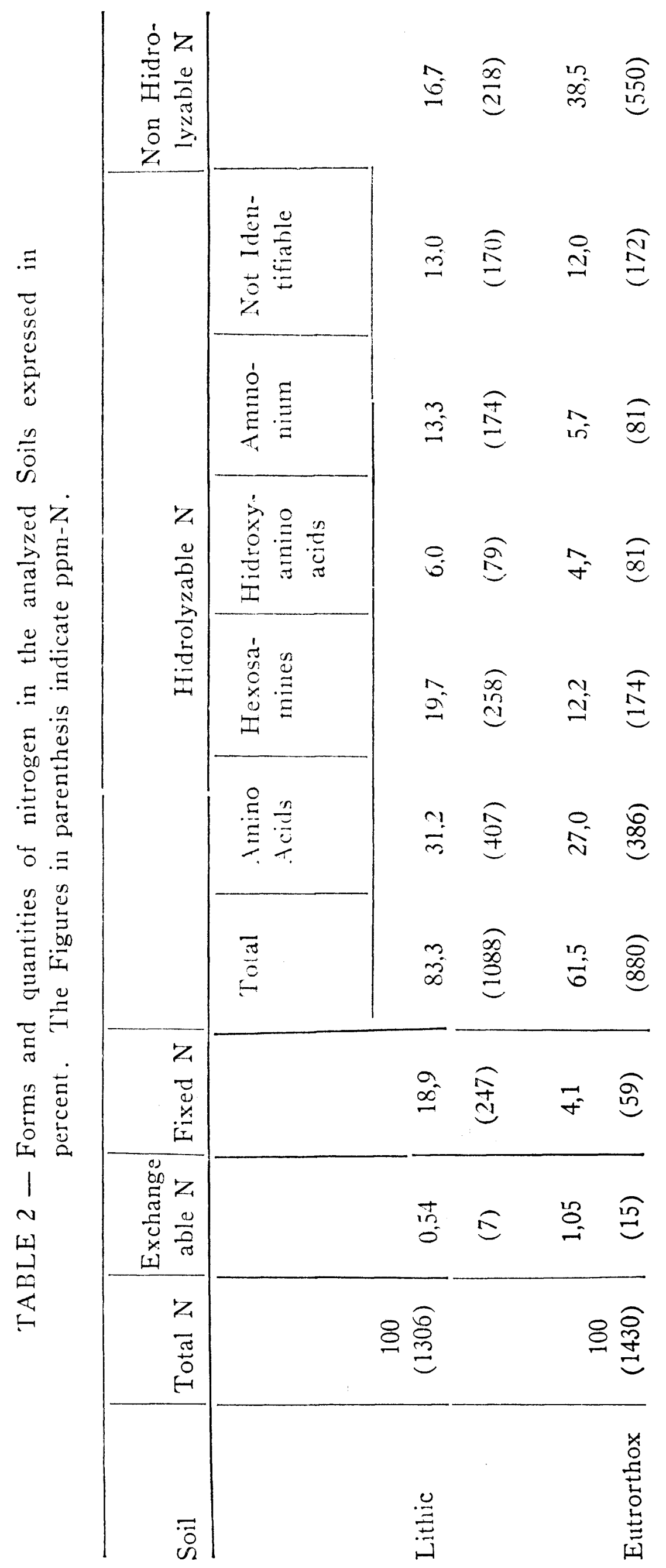


The mineral forms of nitrogen analyses, exchangeable and fixed ammonium, differ largely when the two soils are compared. For the Lithic Haplustoll soil, the exchangeable and fixed ammonium, expressed as nitrogen in ppm, reach 7 and $54 \mathrm{ppm}$, respectively. Of greater interest is the concentration of the same in relative values: 0,54 and $18,9 \%$ of the total soil nitrogen. Literature concerning fixed ammonium content in tropical soils is scarce; however, RODRIGUES, 1954 and recently MIKANI and KANEHIRO, 1968, found, for these soil types, values from 0 to $76 \%$ of the total soil nitrogen in the form of fixed ammonium. Notwithstanding these references, the possibility of encountering soils in which a large part of the total soil nitrogen as in the form of fixed ammonium and possibly not available to plants, does not fail to be surprising.

In the Eutrorthox soil the exchangeable ammonium reaches $15 \mathrm{ppm}$ and the fixed ammonium $59 \mathrm{ppm}$, both accounting for 1 to $4,1 \%$ of the total soil nitrogen, respectively.

The reasons for the these differences in the fixed ammonium content in the two soils should be sought, possibly in the mineralogical, chemical and analytical data on the same (see Table 1). As already pointed out, three of the factors affecting the soil fixed ammonium content are potassium, $\mathrm{pH}$ value and organic matter. The Lithic Haplustoll soil is richer in potassium, but practically there are no differences among them with regard to $\mathrm{pH}$ value and organic matter content. Most authors agree in that potassium influences depressively the ammonium fixation when previously added to ammonium, but as far as native fixed ammonium is concerned, the potassium present in the solution can penetrate into the lattice and cause a collapse of the same. The ammonium is retained in the clay, thus increasing the quantity of fixed ammonium in the soil (ADAMS and STEVENSON, 1964; FRENEY, 1964; HANWAY and SCOTT, 1956; HINMAN, 1966).

Probably the most important cause for the difference in the fixed ammonium content is the predominance of illites and the relatively high content of vermiculite in the Lithic Haplustoll soil as compared to the Eutrorthox soil, in which kaolinite is predominant. It is known of the participation of 2:1 clay in the ammonium fixation, however it is convenient to point out that the correlation between this type of clay and ammonium fixation is not always direct. Some authors, KAILA, 1966; MIKAMI and KANEHIRO, 1968; YOUNG, 1964, found a high, correlation between both, while others, BURGE and BROADBENT, -961; WALSH and MURDOCK, 1963 did not find such a correlation.

The results of the hydrolysis of soils show that it was $83,3 \%$ effective in Lithic Haplustoll and only $61,5 \%$ effective in Eutrortox. The cause for this resistance to hydrolysis is generally attributed to the presence of organic-mineral complexes which protect the organic fraction atainst the action of the $6 \mathrm{~N} \mathrm{HC1}$ utilized. Despite the fact 
that many authors believe the montmorillonite to be the major factor in the formation of these complexes and kaolinite the littlest one, BREMNER, 1967, ARSHAD and LOWE, 1966 demonstrated that the organo-mineral complexes were associated with the coarse fraction of the studied soils, in which kaolinite was predominant and they cite also works by which it was possible to demonstrate that calcium, aluminum and iron may be involved in the absorption of humus by clay.

The mineralogical and chemical analyses of the soils under study (see Table 1) enables one to presume that these two latest remarks explain the difference in which the soils reacht in the hydrolysis. The Eutrorthox soil, with predominance of kaolinite and higher iron and aluminum enrichment presents greater resistance to hydrolysis.

In the hydrolyzable fraction of the soils under study the variation in the content of total nitrogen in the hydrolyzate in the two soils is attributed to the differences already discusses in the previous paragraph. The values for serine and threonine, assembled under the name of hydroxyaminoacids (SILVA and BREMNER, 1966) and the values for amino acids, are within the expected results found in the literature consulted (KEENEY and BREMNER, 1966). These authors and STEVENSON, 1957, found much lower relative values for hexoseamines than those for the soils under study, but in the literature reviewed, no data were found related to hexoseamines for soils of tropical regions. The ammonium in the hydrolyzate for Lithic soil shows higher values than those for Eutrorthox soil. Possibly the cause for this is due to the fact that a considerable part of the ammonium present in the hydrolyzate derives from the clay fixed ammonium, since there is evidence that hydrolysis with $6 \mathrm{~N}$ HC1 releases a large part of the fixed ammonium (CHENG and KURTZ, 1963; SOWDEN, 1958). From the comparison of the data for fixed ammonium with ammonium in the hydrolyzate of the soils, it is possible to conclude that the higher ammonium content in the hydrolyzate of the Lithic Haplustoll soil fraction may be due to a more intense release of the fixed ammonium of this soil.

It is interesting to point out, finally, that the non identifiable nitrogen in the hydrolyzate is practically equal in the two soils under study, and smaller than found by KEENEY and BREMNER, 1967.

\subsection{Ammonium fixation to the soil}

Table 3 shows the data obtained when the ammonium fixation is determined by the method described by ALLISON et al., 1953a, modified.

In the two soils the ammonium fixation capacity reaches its maximum in two days and declines with the course of time. Literature is not rich in regard to influence of time on ammonium fixation by soil, but it is supposed that maximum fixation occurs in the first 48 hours and after that remains constant (NÕMMIK, 1965). This statement 
TABLE 3 - Capacity of fixation of ammonium expressed in percentage of $\mathrm{NH}_{4}$ added to the soil determined by the method described by Allison et al., 1953a, modified. The corresponding figures in parenthesis express rounded ou values of $\mathrm{N}-\mathrm{NH}_{4} \mathrm{ppm}$

\begin{tabular}{lccccc} 
& \multicolumn{5}{c}{ Period of incubation } \\
\cline { 2 - 6 } Soils & 0 & 2 & 5 & 15 & 30 \\
Eutrorthox & 0 & $26,2(11)$ & $19,0(8)$ & $16,7(7)$ & $11,9(5)$ \\
Lithic & 0 & $19,0(8)$ & $11,9(5)$ & $11,9(5)$ & $7,1(3)$ \\
\hline
\end{tabular}

deserves credit if we consider that all the ammonium which did not appear in the extract after washing either with $1 \mathrm{~N}$ or with $2 \mathrm{~N} \mathrm{KC1}$ may be fixed in the lattice of soil clay, and that it is neither appreciably nitrifiable, leachable, nor removable by plants. This first hypothesis is supported by the majority of authors who work in this field and the second by BOWER, 1950b; PETERBURGSKY and SMIRNOV, 1966; VAN SCHREVEN, 1968; and WALSH and MURDOCK, 1960. However, the results found allow the supposition that: either not all the ammonium unrecovered in the leaching is fixed, or, if so, the fixation is not strong enough to prevent its liberation.

The relative validity of these assumptions becomes more evident by observing the results of Table 4 , which are obtained when the fixation capacity is directly, determined by the decrease of ${ }^{15} \mathrm{~N}$ added to the $2 \mathrm{~N}$ KC1 leaching.

T.ABLE 4 - Capacity of fixation of ${ }^{15} \mathrm{~N}$ ammonium added to the soil, determined as per Nõmmik, 1965, expressed in percent

\begin{tabular}{lccccc}
\hline & \multicolumn{5}{c}{ Period of incubation in days } \\
\cline { 2 - 6 } Soils & 0 & 2 & 5 & 15 & 30 \\
Eutrorthox & 0 & 57,1 & 97,6 & 85,7 & 50,0 \\
Lithic & 0 & 61,9 & 47,6 & 45,2 & 33,3 \\
\hline
\end{tabular}

These data indicate that, only for Lithic Haplustoll soil, maximum fixation of added ammonium was reached at 2 days, while for Eutrorthox soil occurs at 5 days. However, in the 2 soils, the fixation tends to decline in the course of time, as in the previous case. 
The analysis of the data in these 2 Tables indicates that, if the values obtained actually correspond to the ammonium fixed in the clay fraction the ammonium is easily released in the soil solution. Even so the data in Table 4 show that the fixed ammonium determined by the method of extraction with $2 \mathrm{~N} \mathrm{KC1}$, is not solely constituted by the added ammonium, as was expected within the accepted criterion of fixation capacity. For the Eutrorthox soil, the maximal participation of the added ammonium in the fixed ammonium was $97,6 \%$, but on the $30^{\text {th }}$ day after being incorporated it was only $50 \%$. This fact is still more remarkable for the Lithic Haplustoll soil in which maximum contribution occurs on the $2^{\text {ml }}$ day with $61,9 \%$ and the minimum, also on the $30^{\text {th }}$ day, with $33,3 \%$.

The following table shows the data corresponding to the analyses of fixed ammonium from a labelled ${ }^{1} \mathrm{~N}$ ammonium sulphate solution and determined in accordance with SILVA and BREMNER, 1966.

It is believed that the noteworthy differences, that appear when comparing the values show in Tables 3,4 and 5 , are due, as already pointed out, to the fact most of the methods to determine the capacity to fix the added ammonium through extraction with $1 \mathrm{~N}$ or $2 \mathrm{~N} \mathrm{KC1}$ are based on the fact that all the ammonium which is not extracted is retained between the clay lattice.

The data in Table 5 seem to demonstrate that this supposition is not correct, since except the value obtained on the $15^{\text {th }}$ day for Eutrorthox soil, the capacity of fixation does not exceed $5 \%$ of the quantity of ammonium added in the two soils. It is presumable that the determination of capacity of ammonium fixation (added ammonium) through extraction with $\mathrm{KC} 1$ covers two facts:

TABLE 5 - Capacity of fixation of ammonium, expressed in percent of adlled ammonium, determined in accordance with Silva and Bremner, 1966. The figures in parenthesis correspond to rounded out values in $\mathrm{N}-$ ${ }^{15} \mathrm{NH}^{+}{ }_{4} \mathrm{ppm}$

\begin{tabular}{lccccc}
\hline & \multicolumn{5}{c}{ Period of } \\
\cline { 2 - 6 } Soils & 0 & 2 & 5 & 15 & 30 \\
Eutrothox & 0 & $4,8(2)$ & $4,8(2)$ & $11,9(5)$ & $2,4(1)$ \\
i.ithic & 0 & $4,8(2)$ & $4,8(2)$ & $4,8(2)$ & $4,8(2)$ \\
\hline
\end{tabular}

1. possibility of another form of fixation and/or added ammonium immobilization besides that observed in clays; 
2. the influence of the ammonium already present in the soil solution on the fixation of the added ammonium.

Table 6 makes it possible to estimate the participation of microbial activity in the fixation of added ammonium.

TABLE 6 - Capacity of fixation of ammonium, expressed in percent of ammonium added to previously sterilized soils and determined in accorlance with Allison et al., 1953a, modified. The figures in parenthesis correspond to rounded out values in $\mathrm{N}-{ }^{15} \mathrm{NH}^{+}{ }_{4} \mathrm{ppm}$

\begin{tabular}{lccccc} 
& \multicolumn{5}{c}{ Period of } \\
\cline { 2 - 6 } Soils & 0 & 2 & 5 & 15 & 30 \\
Eutrorthox & 0 & $11,9(5)$ & $4,8(2)$ & $9,5(4)$ & $2,4(1)$ \\
Lithic & 0 & $11,9(5)$ & $7,1(3)$ & $0(0)$ & $7,1(3)$ \\
\hline
\end{tabular}

The elimination of microbial activity in the soil by sterilizing it brings as a consequence a fall in the capacity of fixation evidenced by the comparison of value in Tables 3 and 6. Previous sterilization of soils made it also possible, by confronting the results in Table 5 and 6 , to discriminate fixation of ammonium in clay from that retained through non biological processes.

The possible causes for the differences found when the 3 methods are compared may be attributed to the fact that the method which determines the ammonium fixation by extraction with $2 \mathrm{~N} \mathrm{KC} 1$ is unable to discriminate the different means by which the ammonium disappears from the soil solution, attributing its fixation in clay and its inclusion, through either microbial activity or not, in the other soil fractions.

This fact probably expains the contradictions often found in literature regarding avaiability of fixed ammonium. References have been made to authors who found that fixed ammonium hardly passes to soil solution, or hardly undergoes nitrification, but ALLISON et al., 1953a; AXLEY and LEGG, 1960; and LEGG and ALLISON, 1959 found opposite results. It is believed that larger or smaller availability of ammonium not extracted by either $1 \mathrm{~N}$ or $2 \mathrm{~N} \mathrm{KC1}$ is related to other fractions and not to the ammonium fixed between the clay lattice. This can also explain the conclusion drawn by BLASCO and CORNFIELD, 1966 that the ammonium fixed after being incorporated to the soil is more easily transformed to exchangeable ammonia than the native fixed ammonium. 


\subsection{Immobilization and mineralization of ammonium in the soil}

The processes of immobilization and mineralization of ammonium in soil were estimated through increase or decrease of exchangeable ammonium and of the nitrogen organic forms. The values for the nitrogen isotopic ratios corresponding to the forms studied permit to discriminate the contributions of the soil ammonium and of the added ammonium. For this evaluation the participation of fixed ammonium will not be considered.

Table 7 shows the corresponding values to the evaluation of the mentioned processes for Eutrorthox soil. Without taking into consideration the variation in the total nitrogen content in the hydrolyzate, which is practically only a reflex of what is happening in the other

TABLE 7 - Evaluation of the processes of inmobilization and mineralization of ammonium in entrortrox soil. The contribution of the soil and of the fertilizer to the transformations of the forms studied is expressed in percentage. The figures in parenthesis correspond to $p p m \mathrm{~N}$ $\mathrm{S}=$ soil $; \mathrm{F}=$ fertilizer $; \mathrm{T}=$ total.

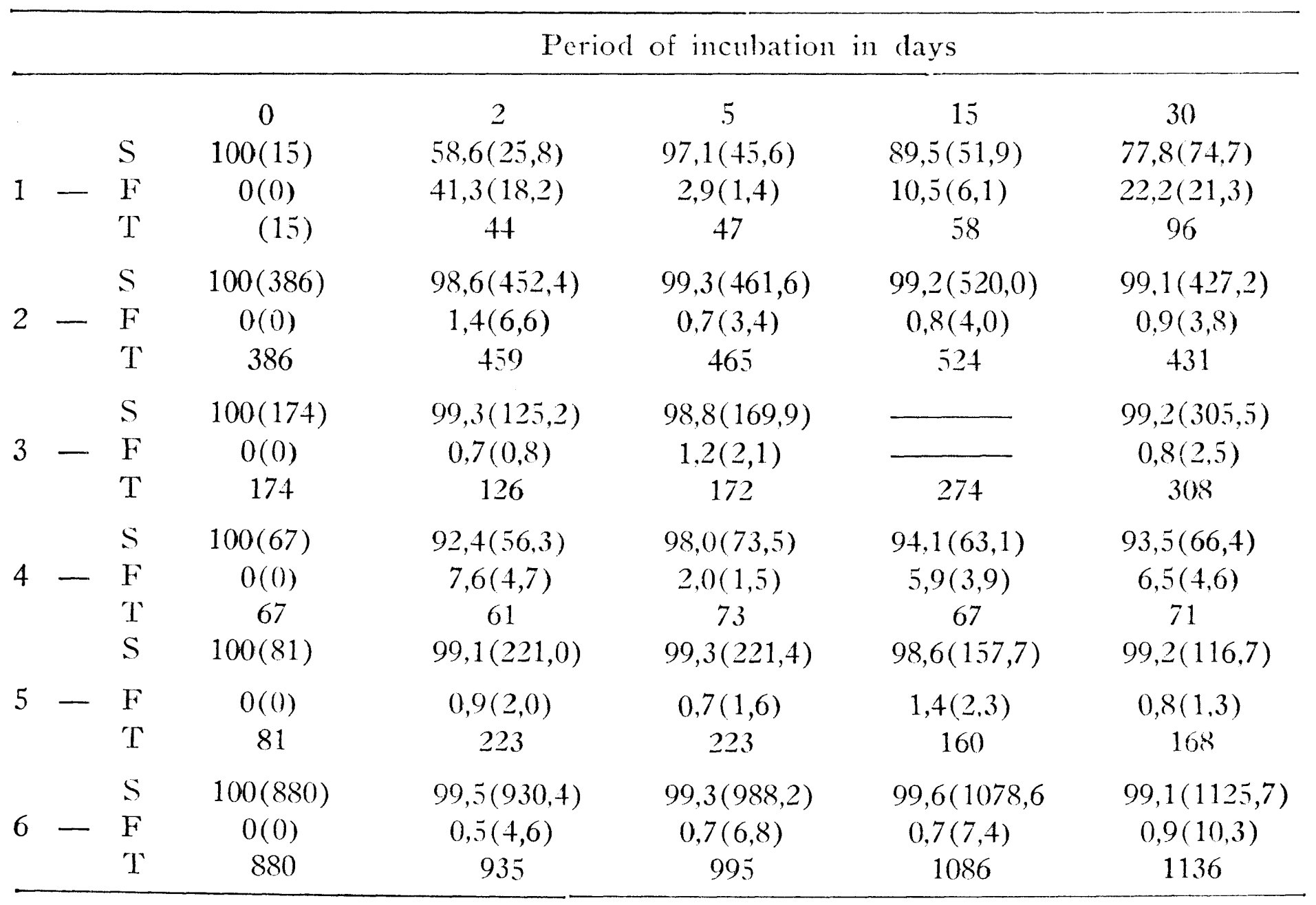

$1=$ Exchangeable ammonium; $2=$ Amino acids $3=$ Hexosamines $4=$ Hydroxyaminoacids; $5=$ Ammonium in hydrolyzate; $6=$ Total $\mathrm{N}$ in the hydrolyzate. 
forms, those which vary significantly with lenght of time of incubation are constituted of amino acids, hexoseamines, ammonium in the hydrolyzate and exchangeable ammonium.

The amino acids, which on the first day reach $386 \mathrm{ppm}$, increase in content up to the $15^{\text {th }}$ after incubation is started, reaching $520 \mathrm{ppm}$ next coming down to $431 \mathrm{ppm}$. In other words, the immobilization of nitrogen in the soil, in the form of amino acids, reaches its maximum 15 days after the experiment is started, after which the processes of mineralization of amino acids begin, evidenced by the decrease in the content of the latter. It is interesting to note that the participation of added ammonium in the variations of amino acid content show opposite trends to those described. This participation, expressed in percentage of total amino acid, is of $1.4 \%$ on the $2^{\text {nd }}$ day, then abruptly falls and, after remaining constant up to the $15^{\text {th }}$ day, shows an increase on the $30^{\text {th }}$ day.

The hexoseamine in soils suffers a rapid decrease up to the second day, and as from there, a constant increase. It is observed that contrary to what occurs with amino acids, in the hexoseamines the mineralization processes take place first, the immobilization processes occurring subsequently. The tendency of the participation of added ammonium in the increase of hexoseamines follows a different path, as in the previous case.

The ammonium in the hydrolyzate behave similarly to amino acids, as far as the influence of incubation period in its content is concerned. In spite of this influence being less drastic, the ammonium in the hydrolyzate initially shows an increase in content, immobilization and, early through the first 5 days, a decrease in its content (mineralization) througt the remaining period of he experiment. Again the participation of the added ammonium doess not follow the described tendency.

The transformations with time that the mentioned forms undergo are similar to those found by other authors. (BROADBENT, 1968; KENNEY and BREMNER, 1966; REID et al., 1969; STEWART et al., 1963).

The fact that the added ammonium does not follow the changes in the soil nitrogen organic forms studied, is hard to explain in the face of the literature consulted. However, attributing the phenomenon of increase or decrease in content of the mentioned forms exclusively to disappearance or appearance of ammonium in soil solution may not be the wisest conclusion. It is probable that the transformations of the nitrogenous organic forms in soils are being processed without necessarily having to take the form of ammonium, that is, an organic form can permit the formation of others directly, through biological or not biological processes.

In spite of the considerations, it is evident that in accordance with the data on Table 7 , the changes in exchangeable ammonium content 
are related to those in the nitrogenous organic forms under study. The slow increase in the first 15 days of incubation can be related with the rapid immobilization verified for the amino acids and not made up for the initial mineralization of hexoseamines or that produced in the ammonium of the hydrolyzate on the $5^{\text {th }}$ day of incubation. Between 5 and 15 days for the ammonium in the hydrolyzate, and 15 to 30 days for the amino acids, a rapid process of mineralization of these two forms takes place, what can explain the increase of nearly $70 \%$ in the content of exchangeable ammonium recorded on the $30^{\text {th }}$ day.

The results of Lithic Haplustoll soil incubation (Table 8) are, in general, similar to those for Eutrorthox. Even so, the variations with lenght of time of incubation of fixed ammonium and of hydroxyamino acids is minimal. The appreciable differences regarding the Eutrorthox

TABIE 8 - Evaluation of the processes of immobilization and mineralization of ammonium in lithic haplustoll soil. Contribution of soil and fertilizer are expressed in percent. The figures in parenthesis correspond to ppm N. $\mathrm{S}=$ soil; $\mathrm{F}=$ fertilizer; $\mathrm{T}=$ total.

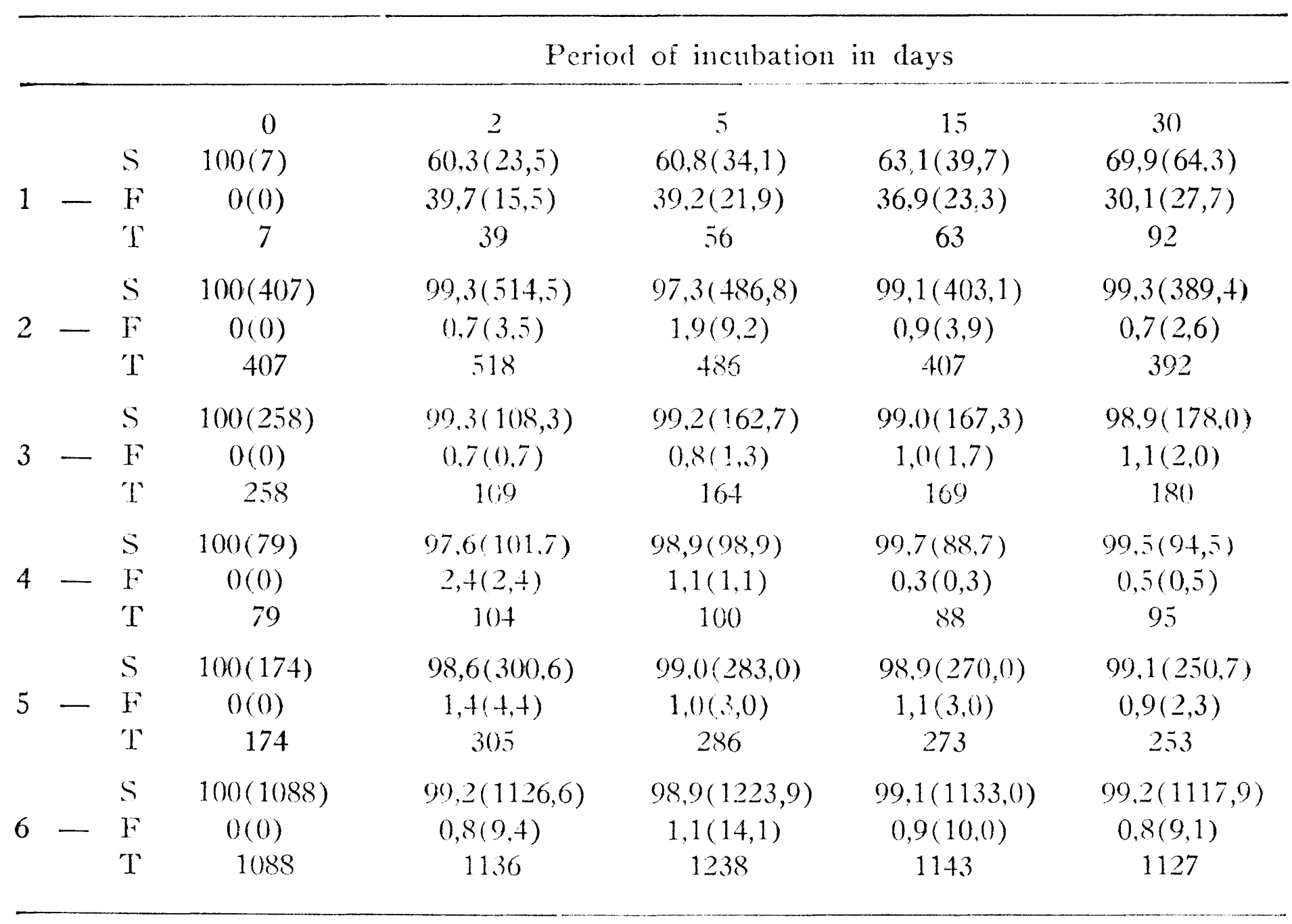

$1=$ Exchangeable ammonium; $2=$ Amino acids $; 3=$ Hexosamines $; 4=$ Hydroxyaninoacids; $5=$ Ammonium in hydrolyzate; $6=$ Total $\mathrm{N}$ in the hydrolyzate. 
appear fundamentally during the periods in which maximum immobilization of soil nitrogen is produced and in the participation of the added ammonium in the variations in the content of the nitrogenous forms studied. For the amino acids and the ammonium in the hydrolyzate, the immobilization occurs on the $2^{\text {nd }}$ day of incubation, then constantly decreasing throught the end of the experiment. The behaviour of these forms probably explains the less abrupt increase the exchangeable ammonium undergoes through the periods of incubation. Hexoseamines, as in the previous case, undergo an initial decrease in their content and shortly after, a constant increase with time. In respect to the added ammonium contribution in the transformations observed, the results largely differ from those found for Eutrorthox soil. In the Lithic Haplustoll soil, the increase of labelled nitrogen follows the content variations of the forms analysed. However, this circumstance is not inconsistent with the possible explanation given when the participation of added ammonium in the processes under study was discussed in regard to Eutrorthox soil.

Table 9 shows the results obtained when the partial added ammonium contributions to the nitrogen forms in study are added up.

TABLE 9 - Percent recovery of added ammonium at the different lengths of time of incubation. The figures in parenthesis correspond to $\mathrm{N}^{-15} \mathrm{NH}_{4} \mathrm{ppm}$

\begin{tabular}{lcccc}
\hline & \multicolumn{4}{c}{ Period of inculation in days } \\
\cline { 2 - 4 } Soils & 2 & 5 & 15 & 30 \\
Eutrorthox & $81(34)$ & $28(12)$ & $52(22)$ & $81(34)$ \\
Lithic Haplustoll & $67(28)$ & $90(38)$ & $81(34)$ & $86(36)$ \\
\hline
\end{tabular}

The values thus found indicate the fate of added ammonium. The amount of added ammonium which does not appear in the forms studied is believed to remain in the non hydrolyzate fraction of soil nitrogen. Observed variations with lenght of time make it presumable that the added ammonium is relatively movable among the hydrolyzable and non hydrolyzable fractions.

The effect of sterilization on immobilization and mineralization of ammonium in the two soils are shown in Tables 10 and 11.

The first fact to be pointed out from the observation of the data in Tables 10 and 11 is that the processes by which soil nitrogen is incorporated into and released in the forms analysed are realized without participation of microbial activity. This statement is supported by the 
TABLE 10 - Sterilization effect on the process of immobilization and mineralization of ammonium in eutrorthox soil. The data are given in ppm-N.

\begin{tabular}{lrrrrr}
\hline & \multicolumn{5}{c}{ Period of incubation in days } \\
\cline { 2 - 5 } FORMS & 0 & 2 & 5 & 15 & 30 \\
Exchangeable ammonium & 15 & 40 & 55 & 48 & 47 \\
Amino acids & 386 & 353 & 351 & 483 & 308 \\
Hexoseamines & 174 & 179 & 263 & 199 & 277 \\
$\begin{array}{l}\text { Hydroxyamino acids } \\
\text { Ammonium in the } \\
\quad \text { hydrolyzate }\end{array}$ & 67 & 67 & 68 & 65 & 66 \\
$\begin{array}{l}\text { Total N in the } \\
\text { hydrolyzate }\end{array}$ & 81 & 220 & 146 & 343 & 110 \\
& 880 & 980 & 1006 & 1198 & 909 \\
\hline
\end{tabular}

TABLE 11 - Sterilization effect on the processes of immobilization mineralization of ammonium in lithic soil. The values are shown in ppm-N.

\begin{tabular}{|c|c|c|c|c|c|}
\hline \multirow[b]{2}{*}{ FORMS } & \multicolumn{5}{|c|}{ Period of incubation in days } \\
\hline & 0 & 2 & 5 & 15 & 30 \\
\hline Exchangeable ammonium & 7 & 44 & 55 & 58 & 49 \\
\hline Amino acids & 407 & 463 & 363 & 377 & 394 \\
\hline Hexoseamines & 258 & 175 & 189 & 168 & 191 \\
\hline Hydroxyamino acids & 79 & 94 & 81 & 107 & 98 \\
\hline Ammonium in the & 174 & 269 & 211 & 270 & 220 \\
\hline $\begin{array}{l}\text { Total } N \text { in the } \\
\text { hydrolyzate }\end{array}$ & 1188 & 1299 & 1201 & 1221 & 1250 \\
\hline
\end{tabular}

results obtained in the evaluation of the efficiency of sterilization. The theories trying to explain the phenomenon of non biological retention of ammonium in the soil have been introduced already, however they are not based either on these methods or on the forms analysed in the present work; therefore it is not possible to build considerations related to the mechanism of incorporation and liberation of nitrogen in soil organic forms.

In spite of that, from the comparison of Tables 7,10 and 11 it is observed that the forms which are the most sensitive to sterilization 
are the amino acids and exchangeable ammonium, since hexoseamines and the ammonium in the hydrolyzate vary little and, when they do, the sterilization effect is stimulating.

The amounts of amino acids and exchangeable ammonium seem to be more subject to microbial activity than the other forms. This dependence is more evident for the exchangeable ammonium in which the content practically does not vary with the lenght of incubation time.

\section{CONCLUSIONS}

The results obtained enable us to suggest that:

1. Possibly for some soils the presence of appreciable amounts of fixed ammonium limits the validity of results obtained when the total nitrogen is estimated by the conventional methods.

2. The use of 1 or $2 \mathrm{~N} \mathrm{KC1}$ extraction is not probably an adequate method for the determination of the capacity to fix ammonium, for its inefficiency in discriminating the paths through which the ammonium disappears in the solution. It would be better to assume that it determines the capacity of retention of the ammonium added to the soil. It must considered that this term is more appropriate, because it includes the phenomena of fixation, biological or not, and of immobilization.

3. The soil capacity to fix ammonium is better characterized using the method of SILVA and BREMNER, 1966, when the solution used to estimate is ${ }^{15} \mathrm{~N}$ enriched.

4. The increase in the content of exchangeable ammonium in the soil is related with the decrease in the content of amino acids and of ammonium in the hydrolyzate. Hexoseamines increase with lenght of time incubation and hydroxyamino acids seem not to participate in these transformations.

5. The added ammonium which do not appear in the nitrogenous forms studied can be considered as retained in the non hydrolyzable soil fraction. However it is probable that the same is relatively movable.

6. The processes through which soil nitrogen is incorporated into or released in the nitrogenous forms studied continue, in higher or lower degree, when microbial activity is eliminated. The forms which are the most affected in their contents by this situation are the amino acids and the exchangeable ammonium, which are likely to depend more on the biological processes than on the other forms. 


\section{SUMMARY}

PROCESS OF FIXATION, IMOBILIZATION AND MINERALIZATION OF AMMONIUM IN SOIL, USING ${ }^{15} \mathrm{~N}$

The organic and inorganic forms of soil nitrogen and how they participate in the process of fixation, immobilization and mineralization of ammonium in soils were evaluated, after different periods of incubaton, utilizing two soils, a Lithic Haplustoll and a Typic Eutrorthox.

The results obtained permit to suggest that:

1) The method for determination of the ammonium fixing capacity based on the extraction with $2 \mathrm{~N} \mathrm{KCl}$, is considered to be sulbject to interferences of other soil fractions capable of retaining ammonium.

2) The increase in exchangeable ammonium content is related to the decrease in anino acids and hydrolyzäble ammonium.

3) The immobilization and mineralization processes are still held under mil microbial. The forms more affected by this condition are amino acids and hydrolyzable ammonium.

\section{LITERATURA CITADA}

ADAMS, R.S. and STEVENSON, F.J., 1964. Ammonium sorption and release from rocks and minerals. Soil Sci. Soc. Amer. Proc. 28:345-351.

ALLISON, F.E., IOETSCH, J.H. and ROLLER, E.M., 1953. Ammonium fixation and availability in vermiculite. Soil Sci. 75:173.180.

ARSHARD, M.A. and LOWE, E.L., 1966. Fractionation and characterization of naturally occurring organo-clay complexes. Soil Sci. Soc. Amer. Proc. 30:731-735.

AXLEY, J.H. and LEGG, J.O., 1960. Ammonitm fixation in soils and the influence of $\mathrm{K}$ on $\mathrm{N}$ availability from nitrate and ammonium sources. Soil Sci. 90:151-156.

BLASCO, M.L. and CORFIELD, A.H., 1966. Fixation of added $\mathrm{NH}_{4}$ and nitrification of fixed $\mathrm{NH}_{4}$ in soil clays Sci. Fd. Agric. 17: 481-484.

BOWER, C.A., 1950b. Fixation of ammonium in difficult exchangeable form under moist conditions by some soils of semiarid regions. Soil Sci. 70:375-384.

BREMNER, J.M., 1959. Determination of fixed ammonium in soils. J. Agric. Sci. $52: 147-160$.

BREMNER, J.M., 1965. Inorganic forms of nitrogen. In C.B. Black et al. (eds.). Methods of Soil Analysis. Agron. 9:1179-1237.

BREMNER, J.M., 1965c. Isotope-ratio analysis of nitrogen in nitrogen-15 tracer investigations. In C.A. Black et al. (eds.). Methods of Soil Analysis, Parte 2. Argonomy $9: 1256-1286$. 
BRE.MNER. I.M., and EDWARDS, A.P., 1965. Determination and isotope-ratio analysis of different forms of $\mathrm{N}$ in soils: 1. Apparatus and procedure for distilation and determination of ammonium. Soil Sci. Soc. Amer. Proc. 29: 504-507.

BREMNER, I.M. and KEENEY, D.R., 1966. Deternination and isotope-ratio analysis of different forms of $\mathrm{N}$ in soils: 3. Exchangeable $\mathrm{NH}^{+}{ }_{4}, \mathrm{NO}_{2}$ by extraction-destilation methods. Soil Sci. Soc. Amer. Proc. $30: 577-582$.

BREMNER, J.M., 1967. Nitrogenous compounds. In A.D. McLaren e G.H. Peterson (eds.). Soil Biochemistry, Marcel Dekker lne. N.Y., pg. 19-66.

BROADBENT, F.E., 1968. Nitrogen immobilization in relation to $\mathrm{N}$-containing fractions of soil organic matter. In lsotopes and radiation in soil organic matter studies. Proceeding of a Symposium, IAEA/FAO - Vient.

BURGE, W.D. and BROADBENT, F.E., 1961. Fixation of ammonia by organic soils. Soil Sci. Soc. Am. Proc. $25: 199.204$.

CATANi, R.A., GAllo, J.R., and GARGANTini, H., 1955. Amostragen de Solo. Métodos de análise. Interpretação e indicações gerais para fins de fortilidade. I.A.C.

- São Paulo, Brasil.

CHENG, H.H., and KURTZ, L.T., 1963. Chemical distribution of added nitrogen in soils. Soil Sci. Soc. Am. Proc. 27 :312-316.

DEMATTE, J.L.I. Personal Communication.

ESCOBAR, E.H., 1969. Gênese e classificação de alguns solos da bacia do Ribeirão Tijuco Preto - Município de Rio das Pedras - Tese de M.S. - E.S.A.L.Q. - Piracicaba, $\mathrm{SP}$, Brasil.

FRENEY, J.R., 1964. An evaluation of naturally occurring fixed ammonium in soils. J. Agric. Sci. $63: 297-303$.

HANWAY, J.J. and SCOTT, A.D., 1956. Ammonium fixation and release in certain Iowa soils. Soil Sci. 82:379-386.

HINMAN, W.C., 1966. Ammonium fixation in relation to exchangeable $\mathrm{K}$ and organic matter content in two soils. Canad. J. Soil Sci. 46:223-225.

KATLA, A., 1966. Fixed ammonium in some Finnish soils. J. Scient. Agroc. Soc. Finl. 38: 49--58. [Soil and Fertilizers 29 (2983)].

KEENEY, D.R., BREMNER, J.M., 1966. Determination and isotope-ratio analysis of different forms of $\mathrm{N}$ in soils: 4. Exchangeable $\mathrm{NH}_{4}, \mathrm{NO}_{3}$ and $\mathrm{NO}_{2}$ by direct destilation methods. Soil Sci. Soc. Amer. Proc. 30:583-587.

KEENEY, D.R. and BREMNER, J.M., 1967. Characterization of Mineralizable $\mathrm{N}$ in soils. Soil Sci. Soc. Am. Proc. 30:714-719.

LEGG, J.O. and ALLISON, F.E., 1959. Recovery of tagged $\mathrm{N}^{15}$ nitrogen from ammonium-fixing soils. Soil Sci. Soc. Am. Proc. 23:131-134.

MIKANI, D.T. and KANEHIRO, Y., 1968. Native fixed ammonium in Hawaiian soils. Soil Sci. Soc. Am. Proc. 32: 481-485.

NÕMMIK, H., 1965. Ammonium fixation and other reactions involving a nonenzymatic immobilization of mineral $\mathrm{N}$ in soil. In W.V. Bartholomeu e F.E. Clark (eds.). Soil Nitrogen Agronomy 10:198-258. 
OLSON, R.A., MEYER, M.W., LAMKE, W.E., WOLTEMATH, A.D., and WEISS, R.F. 1960. Nitrate production rate as a soil test for estimating fertilizer nitrogen requirements of cereal crops. In 7 th Int. Congress of Soil Science, Madison, 11 is. III. 463-470.

PETERBURGSKY, A.V. and SMIRNOV, P.M., 1966. Ammonium fixation in some soils of the U.S.S.R., and the availability of this ion to plants. Plant and Soil 25:119-128.

RANZANI, G., FREIRE, O., and KINJO, T., 1966. Carta de Solos do Município de Piracicaba, Centro de Estudos de Solo. ESALQ. U.S.P. Piracicaba, SP., Brasil.

REID, A.S., WEBSTER, G.R. and KROUSE, H.R., 1969. Nitrogen movement and transformation in soils. Plant and Soil $31: 224-237$.

RITTEMBERG, D., 1946. The preparation of gas samples for mass spectrographic isotope analysis. In Preparation and measurement of isotopic tracers. Ed. Ann. Arbor. Michigan, U.S.A. 31-42.

RODRIGUES, G., 1954. Fixed ammonia in tropical soils. J. Soil Sci. 5:264-274.

SILVA, J.A., and BREMNER, J.M.., 1966. Determination and Isotope-ratio analysis of different forms of $\mathrm{N}$ in soils: 5. Fixed ammonium Soils Sci. Soc. Amer. Proc. 30: $587-594$.

SOWDEN, F.J., 1958. The forms of nitrogen in the organic matter of different horizons of soil profiles. Canad. J. Soil Sci. 38:147-154.

STEVENSON, F.J., 1957. Investigations of aminopolysacharids in soils: 2. Distribution of hexosamines in some soil profiles. Soil Sci. 84:99-106.

STEVART, B.A., PORTER, L.K. and JOHNSON, D.D., 1963. Immobilization and mineralization of $\mathrm{N}$ in several organic fractions of soils. Soil Sci. Soc. Amer. Froc. 27 : 302-304.

VAN SCHREVEN, D.A., 1968. Ammonium fixation and availability of fixed ammoniums in some Dutch loam and clay soils. Neth. J. Agric. Sci. 16:91-102.

YOUNG, J.L., 1964. Ammonia and ammonium reactions with some Pacific Northwest soils. Soil Sci. Soc. Amer. Proc., $28: 339-345$.

WALH, L.M. and MURDOCK, J.T., 1960. Native fixed $\mathrm{NH}_{4}^{+}$and fixation of applied $\mathrm{NH}_{4}$ in several Wisconsin soils. Soil Sci. 89:183-193.

WALSH, L.M., and MURDOCK, J.T., 1963. Recovery of fixed $\mathrm{NH}_{4}^{+}$by corn in greenhouse studies. Soil Sci Soc. Amer. Proc. 27 :200-204. 